\title{
Acute corneal hydrops in a patient with intellectual disability
}

\author{
Shinji Makino
}

Department of Ophthalmology, Jichi Medical University, Shimotsuke, Japan

\section{Correspondence to} Dr Shinji Makino, makichan@jichi.ac.jp

Accepted 6 June 2014

\section{DESCRIPTION}

A 30-year-old woman with intellectual disability (ID) was referred to our hospital with a 1-week history of ocular pain in her right eye. Slit-lamp examination showed marked oedema of the central corneal stroma due to acute hydrops in the right eye (figure 1A), and a central corneal scar in the left eye. Her family reported that she had been rubbing her right eye because of itchiness. Initial treatment included application of a topical hypertonic agent $(4 \% \mathrm{NaCl})$. Three weeks after the initial visit, slit-lamp evaluation revealed central corneal scarring with complete resolution of the corneal oedema (figure 1B).

Keratoconus is a condition in which the cornea assumes a conical shape as a result of thinning of the corneal stroma. Patients with advanced disease may occasionally present with a sudden onset of visual loss accompanied by pain. A diffuse stromal opacity may be noted in the cornea. This condition, referred to as acute corneal hydrops, is caused by the rupture of the Descemet's membrane, followed by an influx of aqueous humour into the corneal stroma. ${ }^{1}$

The prevalence of keratoconus is higher in patients with ID $(50 / 1539(3.2 \%))^{2}$ than in the general population (54.5/100 000 individuals). ${ }^{1}$

Eye rubbing has been implicated in the pathogenesis of keratoconus. ${ }^{3}$ Habitual eye rubbing, which is frequently observed in patients with ID, has been postulated as an important factor for the development of keratoconus itself and for the progression to acute corneal hydrops. In such cases, referral to appropriate ophthalmological care is essential.

\section{Learning points}

- The prevalence of keratoconus is higher in patients with intellectual disability than in the general population.

- Keratoconus and/or acute corneal hydrops should be considered in the differential diagnosis of ocular pain and corneal opacity in patients with intellectual disability.

- Avoidance of rubbing may reduce the incidence of adverse responses in patients with intellectual disability.

\section{Competing interests None.}

Patient consent Obtained.

Provenance and peer review Not commissioned; externally peer reviewed.

\section{REFERENCES}

1 Rabinowitz YS. Keratoconus. Surv Ophthalmol 1998;42:297-319.

2 van Splunder J, Stilma JS, Bernsen RMD, et al. Prevalence of ocular diagnoses found on screening 1539 adults with intellectual disabilities. Ophthalmology 2004;111:1457-63.

3 McMonnies CW. Mechanisms of rubbing-related corneal trauma in keratoconus. Cornea 2009;28:607-15.
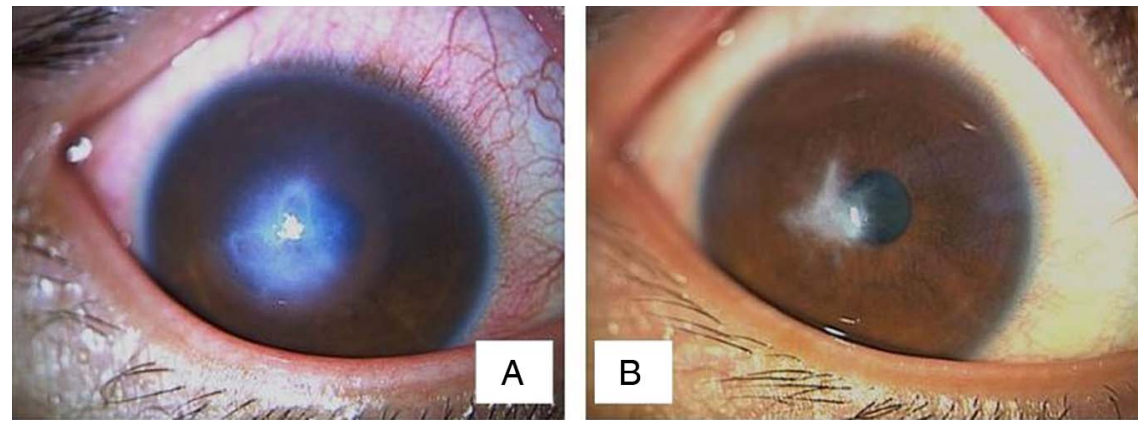

Figure 1 Slit-lamp photograph showing severe acute corneal hydrops and stromal oedema in the right eye (A). The central corneal scar with complete resolution of stromal oedema after medical treatment in the right eye 3 weeks later (B). 


\section{Images in...}

Copyright 2014 BMJ Publishing Group. All rights reserved. For permission to reuse any of this content visit http://group.bmj.com/group/rights-licensing/permissions.

BMJ Case Report Fellows may re-use this article for personal use and teaching without any further permission.

Become a Fellow of BMJ Case Reports today and you can:

- Submit as many cases as you like

- Enjoy fast sympathetic peer review and rapid publication of accepted articles

- Access all the published articles

- Re-use any of the published material for personal use and teaching without further permission

For information on Institutional Fellowships contact consortiasales@bmjgroup.com

Visit casereports.bmj.com for more articles like this and to become a Fellow 